\title{
Neuropsychology of the frontal lobe and III functional brain unit: A Luria's studies and perspectives for the clinic approach
}

\author{
Neuropsicologia do lobo frontal e III unidade funcional do cérebro: Estudos de Luria e \\ perspectivas para a abordagem clínica \\ Neuropsicología del lóbulo frontal y III unidad funcional cerebral: Estudios de Luria y perspectivas \\ para el enfoque clínico
}

\author{
Karolyne Cordeiro-de-Oliveira \\ ORCID: https://orcid.org/0000-0002-6256-1968 \\ Federal University of Alfenas, Brazil \\ E-mail: karolyne.cordeiro@sou.unifal-mg.edu.br \\ Dyecika Souza-Couto \\ ORCID: https://orcid.org/0000-0002-1801-7666 \\ Federal University of Alfenas, Brazil \\ E-mail: dyecikacouto99@gmail.com \\ Marcelo Caixeta \\ ORCID: https://orcid.org/0000-0003-2357-6558 \\ Núcleo de Pesquisas Psiquiátricas. CERNE, Brazil \\ E-mail: marcelofcaixeta@gmail.com \\ Victor Caixeta \\ ORCID: https://orcid.org/0000-0003-2433-3128 \\ Núcleo de Pesquisas Psiquiátricas. CERNE, Brazil \\ E-mail: vmcaixeta@gmail.com \\ Tales Alexandre Aversi-Ferreira \\ ORCID: https://orcid.org/0000-0002-4417-7209 \\ Federal University of Alfenas, Brazil \\ E-mail: tales.ferreira@unifal-mg.edu.br
}

\begin{abstract}
The russian Alexander Romanovich Luria, commonly credited as the father of modern neuropsychology, was responsible for the greater understanding of human psychic and behavioral processes. Through studies on brain injuries, Luria tried to generate an integrative and logical theory for brain functions, in other words, to develop further technical studies on mental functions. To this end, he divides the general brain activities into three units, the first having the function of maintaining surveillance, the second being responsible for obtaining, processing, integrating and storing the information provided by the environment, and the third unit is responsible to plan, execute and direct the pattern of human behavior. Thus, the aim of this study is to review the frontal lobe (FL) neuropsychology and to associate it with the third functional unit of Luria. The references of the book "The Working Brain" were used. In the end, it was possible to conclude from Luria's conceptions that the third functional unit is responsible for the stimuli synthesis, preparation for action, program constructions, verification of the activity's ways, generation of activation process linked to the most complex conscious actions and a speech collaboration.
\end{abstract}

Keywords: Frontal lobe; Neuropsychology; Luria.

\section{Resumo}

O russo Alexander Romanovich Luria, comumente creditado como pai da Neuropsicologia moderna, foi um dos responsáveis pela maior compreensão dos processos psíquicos e comportamentais humanos. Através de estudos sobre lesões cerebrais, Luria tentou gerar uma teoria integrativa e lógica para as funções cerebrais, ou seja, elaborar mais estudos técnicos sobre as funções mentais. Para isto, ele dividiu as atividades gerais do cérebro dentro de três unidades, a primeira cuja função é manter a vigília, a segunda que é responsável por obter, processar, integrar e armazenar as informações obtidas pelo ambiente, e a terceira unidade, responsável por planejar, executar e direcionar o padrão de comportamento humano. Dessa forma, o objetivo deste trabalho é revisar a neuropsicologia do lobo frontal (LF) e associar com a terceira unidade funcional de Luria. Para isto, foram utilizadas as referências do livro "Fundamentos de Neuropsicologia". Ao final, foi possível concluir a partir das concepções de Luria que a terceira unidade funcional é responsável pela síntese de estímulos, preparo para ações, construção de programas, verificação de etapas para realização de atividades, geração do processo de ativação vinculado às ações conscientes mais complexas e colaboração com a fala. 
Palavras-chave: Lobo Frontal; Neuropsicologia; Luria.

\section{Resumen}

El ruso Alexander Romanovich Luria, comúnmente reconocido como el padre de la neuropsicología moderna, fue responsable de una mayor comprensión de los procesos psíquicos y conductuales humanos. A través de estudios sobre lesiones cerebrales, Luria intentó generar una teoría integradora y lógica de las funciones cerebrales, es decir, desarrollar más estudios técnicos sobre las funciones mentales. Para ello, las actividades cerebrales generales son divididas en tres unidades, la primera tiene la función de mantener la vigilancia, la segunda se encarga de obtener, procesar, integrar y almacenar la información que brinda el entorno, y la tercera unidad se encarga de planificar, ejecutar y dirigir el patrón de comportamiento humano. Así, el objetivo de este estudio es revisar la neuropsicología del lóbulo frontal (FL) y asociarla con la tercera unidad funcional de Luria. Se utilizaron las referencias del libro "The Working Brain". Al final, se pudo concluir a partir de las concepciones de Luria que la tercera unidad funcional es responsable de la síntesis de estímulos, preparación para la acción, construcción de programas, verificación de los caminos de la actividad, generación de procesos de activación ligados a las acciones conscientes más complejas y un colaboración de voz.

Palabras clave: Lóbulo frontal; Neuropsicología; Luria.

\section{Introduction}

Some papers and in the preface of Luria's books, researchers such as Oliver Sacks (Luria, 1987b), and Michael and Sheila Cole (Luria, 1979), wrote about the important contribution of this scientist to neuroscience, and to neuropsychology specifically (Aversi-Ferreira et al., 2019), which developed many studies about brain lesions linking them to alterations in behaviour (Aversi-Ferreira et al., 2010).

Indeed, Vygotsky and Luria's initial works were the base for the development of socio-historic-cultural psychology (Luria, 1979), stating that the mind is constructed not only by the physiological process, but also by the interaction of the individual with society and environment.

However, after the initial time with Vygotsky, in many papers (Luria \& Rapport, 1962; Luria, Simernitskaya \& Tubylevich, 1970; Luria, 1971) and books (Luria, 1966, 1973a, 1973b, 1979, 1987) Luria tried to generate an integrative and logical theory for brain functions, i.e., in a more technical way, considering that the mental functions of the brain work in a similar way to a symphony where each of the brain's "organs" is a musical instrument (Luria, 1973a; Aversi-Ferreira et al., 2010).

Didactically, Luria divided the general activities of the brain into three units - 1] a unit to control and regulate the tone and waking in mental states; 2] the unit to store and to analyses the received information; and 3] the unit to regulate, program and to verify the cerebral activities - stating which of those units form the ground to understanding the different forms of mental activities (for more details see Luria, 1973a). Those units are not located in specific cerebral areas but in several parts of the brain, working in a harmonic conjunction (Aversi-Ferreira et al., 2010).

Thus, a dissociation with the theory of strict localization of cerebral functions, accepted and used by neurologists/psychiatrics such as Broca, Wernicke and many others until now, was substituted by Luria and others as an integrative theory of a brain that works using many areas at the same time to generate a complex response from a stimulus. A fact that deserves a comment is that, until today, most neuroscience books (neuroanatomy, neurophysiology, inter alia) show in their text the brain functions as separated parts with isolated functions.

Probably, Luria's main work in relation to understanding the brain's functions is in the book The Working Brain, in which a detailed summary of neuropsychology studies is explained, discussing each cerebral part (lobes, mainly) and its functions after data from brain lesions and from other authors.

Luria associated the cerebral functions with histological, anatomical, physiological, psychological and behavioural studies to justify his conclusions (Luria \& Rapport, 1962; Luria, 1966, 1971, 1973a, 1979, 1987b). The type of cortex and its layers were used to explain the primary, secondary and tertiary areas into modal and supramodal functions; in particular, Luria focused on the supramodal area to justify the superior cerebral functions (Luria \& Rapport, 1962; Luria, 1966, 1971; Aversi- 
Ferreira et al., 2010). The main superior functions are mainly associated with specific and special cortical structure (Luria, 1973a), the granular cortex located at the prefrontal cortex.

As unraveled, more cortical areas take place for work of the supramodal areas, such as the supplementary cortex anterior to the precentral region, also located at the frontal lobe; and the prefrontal cortex is in the central theme of Luria's study about conscious activities (Luria, 1966, 1973a), probably because of his desire to understand the superior activities in humans. Thus, Luria tried to integrate the three functional units (Luria, 1973a) to explain the conscient human responses to environment from stimuli. However, this idea of integrative functions in the brain was suggested by Vygotsky before Luria (Vygotsky, 2004).

Many considerations about the human behaviour can be unravelled from Luria's study and could be used for psychological analysis and tests as didactical proposes (Barbosa et al., 2021); however, in the occidental world Luria is scarcely known by American psychologists (Luria, 1979; Aversi-Ferreira et al., 2019), and in Brazil psychologists, psychiatrics and educators largely know more of Vygotsky's works (Caixeta et al., 2015a; Caixeta et al., 2015b).

A recent work on the neuropsychology of the temporal lobe shows some differences in the discoveries about this lobe between Luria and modern works; indeed, the approaches were different due to the devices used - ancient compared to modern - such as the new techniques of neuroimaging now used today (Aversi-Ferreira et al., 2019), mainly in relation to epilepsy and hippocampus; about the epilepsy, Luria did not develop a detailed analysis and the hippocampus function were not studied deeply.

Similarly, the goal of this work is to review the neuropsychology of the frontal lobe (FL) and its association with the concept of the third functional unit purposed by Luria.

\section{Material and Methods}

In order to write this systematic review, books and articles written by Luria were studied, as well as those with his collaborators, mainly Vygotsky, and other articles cited by Luria in his books 'The Working Brain" (Luria, 1973) listed in the references of this book and found translated to English. Plus, nowadays articles, books and books chapters - in total there were 14 articles, 21 books and 10 book chapters, published after 1973 were used as a basis for this work. The articles written after 1973 were sought, using the descriptors Superior Brain Functions; Brain pathologies, Neuropsychology and Luria; Frontal Lobe and Neuropsychology; Frontal Lobe, Luria and Neuropsychology, on the Capes site, which includes Scopus, Elsevier, Medline, PubMed, SciELO.

The exclusion criteria were based on subjects that were not specifically about the descriptors and in a language other than English or Portuguese, plus articles with similar subjects, from which were chosen the most recent and those that appeared in the journals with the biggest impact factor. All articles presenting the descriptors, and which dealt mainly with Luria's neuropsychology, including the frontal lobe, were included, as well as some papers about the general brain functions and its pathologies.

Some books present data after 1973 because of new editions and translations for Portuguese, however, they were written before this data.

\section{Results}

A scrutinous work to elucidate and to direct other authors to find the base of this articles was performed and shown in the table and figures (Table 1, Figures 1,2). In this way, the superior brain functions were the subject most used in this work followed by articles about the frontal lobe (Figure 2). As neuropsychology is a recent subject, few papers were found and used 
in this work, hence, the most texts dated before 1973 (Figure 1). Furthermore, few articles about the brain's pathologies were used, only those associated with this article's theme.

The data were concatenated in the intersection of the subjects with the frontal lobe and brain pathologies found in many articles and books, and some papers were not used because of the language used i.e., Russian.

Table 1. Data from the bibliographic material used in this work, identifying the titles, subjects and type of text.

\section{Title}

Subject

Type of text
1. $\quad$ Anokhin, P.K. (1949). Problems of Higher Nervous Activity.

2. Anokhin, P. K. (1972). Fundamental Problems in the General Theory of Functional Systems.

3. Artemieva, E. Y., \& Homskaya, E. D. (1966). Changes in asymmetry of the slow waves in various functional states under normal conditions and in lesions of the frontal lobes.

4. Aversi-Ferreira, T. A., Araújo, M. F. P. D., Lopes, D. B., \& Nishijo, H. (2010). History, citoarchitecture and neurophysiology of human and non human primates' parietal lobe: A review.

5. Aversi-Ferreira, T. A., Tamaishi-Watanabe, B. H., Magri, M. P. D. F., \& Aversi-Ferreira, R. A. (2019). Neuropsychology of the temporal lobe: Luria's and contemporary conceptions.

6. Baranovskaya, O. P., \& Homskaya, E. D. (1973). Changes in the electroencephalogram frequency spectrum during the presentation of neutral and meaningful stimuli to patients with lesions of the frontal lobes.

7. Barbosa, S. M. C. ., Silva, H. E. da ., Silva, E. N. \& Lima, L. O. F. (2021). Subjective relationships mediating the teaching constitution process in non school environment . Research, Society and Development, 10(4), e47710413898. https://doi.org/10.33448/rsd-v10i4.13898

8. Bernstein, N. A. (1966). Outlines of the Physiology of Movements and the Physiology of Activity.

9. Brutkowski, S. (1966). Functional peculiarities of the silent zones of the frontal lobes in animals.

10. Brutkowski, S. (1964). Prefrontal cortex and drive inhibition.

11. Brutkowski, S., Konorski, J., Lawicka, W., Stepien, I., \& Stepien, L. (1956). The effect of the removal of frontal poles of the cerebral cortex on motor conditioned reflexes.

12. Caixeta, M. et al., (2015). Vygotsky: Psiquiatria/Psicologia do desenvolvimento. São Paulo: Sparta.

13. Caixeta, M. et al., (2015). Psiquiatria e psicologia do desenvolvimento. São Paulo: Sparta.

14. Durinyan, R. A. \& Rabin, A. G. (1968). Cortical Regulation of Activity of the Subcortical Formations of the Brain.

15. French, J. D., Hernández-Pen, R., \& Livingston, R. B. (1955). Projections from cortex to cephalic brain stem (reticular formation) in monkey.

16. Gross, C. G., \& Weiskrantz, L. (1964). Some changes in behavior produced by lateral frontal lesions in the macaque.

17. Homskaya, E. D. (1966). Vegetative components of orienting reflex to indifferent and significant stimuli in patients with lesions of the frontal lobes.

18. Konorski, J., \& Lawicka, W. (1964). Analysis of errors by prefrontal animals on the delayed-response test.

19. Leontiev, A. N. (1959). Problems of mental development.

20. Livanov, M. N., Gavrilova, N. A., \& Aslanov, A. S. (1964). Intercorrelations between different cortical regions of human brain during mental activity.

21. Luria, A. R. (1966). Higher Cortical Functions in Man.

22. Luria, A. R. (1971). Memory disturbances in local brain lesions.
Superior brain functions

Superior brain functions

Book

Frontal lobes

Book

Superior brain functions

Book chapter

Neuropsychology

Article

Frontal Lobes

Book chapter

Neuropsychology

Superior brain functions

Book

Frontal lobes

Book chapter

Frontal lobes

Book chapter

Frontal lobes

Article

Superior brain functions

Book

Superior brain functions

Book

Superior brain functions

Book

Superior brain functions

Article

Frontal lobes

Book chapter

Frontal lobes

Book chapter

Frontal lobes

Book chapter

Brain pathologies

Superior brain functions

Book

Article

Superior brain functions Superior brain functions
Book

Article 
23. Luria, A. R. (1973a). The working brain: An introduction to neuropsychology.

24. Luria, A. R. (1973b). The neuropsychology of memory.

25. Luria, A.R. (1979). The making of mind.

26. Luria, A. R. (1987a). The Mind of a Mnemonist: A Little Book about a Vast Memory.

27. Luria, A. R. (1987b). The Man with a Shattered World: The History of a Brain Wound.

28. Luria, A. R., \& Rapoport, M. Y. (1962) Regional symptoms of disturbance of the higher cortical function in intracerebral tumours of the left temporal lobe.

29. Luria, A. R., Simernitskaya, E. G., \& Tubylevich, B. (1970). The structure of psychological processes in relation to cerebral organization.

30. Miller, G. A., Galanter, E., \& Pribram, K. H. (1960). Plans and the organization of behavior.

31. McCulloch, W. S. (1943). Interareal interaction of the cerebral cortex.

32. Pandya, D. N., \& Kuypers, H. G. (1969). Cortico-cortical connections in the rhesus monkey.

33. Pavlov, I. P. (1949a). Complete Collected Works, vols. 1-6.

34. Pavlov, I. P. (1949b). Pavlov 's Wednesday Clinics, vols. 1-3.

35. Polyakov, G. I. (1965). Principles of the Neuronal Organization of the Brain.

36. Polyakov, G. I. (1966). Structural organization of the frontal cortex in relation to its functional role.

37. Pribram, K. H. (1960). A review of theory in physiological psychology.

38. Pribram, K. H. (1961). A further experimental analysis of the behavioral deficit that follows injury to the primate frontal cortex.

39. Pribram, K. H. (1971). Languages of the brain: Experimental paradoxes and principles in neuropsychology.

40. Silva, L. P. \& Guaresi, R. (2021). The (dis) symmetrization in initial literacy and its possible association with linguistic and cognitive variables . Research, Society and Development, 10(4), e26310412792. https://doi.org/10.33448/rsd-v10i4.12792

41. Sugar, O., Petr, R., Amador, L. V., \& Griponissiotis, B. (1950). Cortico-cortical connections of the cortex buried in the intraparietal and principal sulci of the monkey (Macaca mulatta).

42. Vygotsky, L. S. (1960). Development of higher psychological function.

43. Vygotsky, L. S. (1956). Selected psychological studies.

44. Vygotsky, L. S. (2004). Teoria e método em psicologia. Sao Paulo: Martins Fontes.

45. Walter, W. G. (1966). Role of the human frontal lobes in the regulation of activity.

\begin{tabular}{lc}
\multicolumn{1}{c}{ Neuropsychology } & Book \\
$\begin{array}{l}\text { Neuropsychology } \\
\text { Superior brain functions } \\
\text { Superior brain functions }\end{array}$ & Book \\
Buperior brain functions & Book \\
Superior brain functions & Book \\
& Article \\
Neuropsychology & Article \\
Superior brain functions & \\
Superior brain functions & Book \\
Superior brain functions & Book chapter \\
Superior brain functions & Article \\
Superior brain functions & Book \\
Superior brain functions & Book \\
Frontal lobes & Book \\
Superior brain functions & Book chapter \\
Frontal lobes & Article \\
Brain pathologies & Article \\
& Book
\end{tabular}

Superior brain functions

Superior brain functions

Article

Superior brain functions

Book

Superior brain functions

Book

Superior brain functions

Book

Frontal lobes

Source: Authors (2021).

The superior brain functions were the most used in this work followed by the articles about the frontal lobe (figure 1). As the neuropsychology is a recent subject few works were found and used and also few articles about the brain pathologies were used, just those associated to the theme this article. 
Research, Society and Development, v. 10, n. 7, e48210716760, 2021

(CC BY 4.0) | ISSN 2525-3409 | DOI: http://dx.doi.org/10.33448/rsd-v10i7.16760

Figure 1. Number of texts separated by the data before or equal 1973 and after 1973.

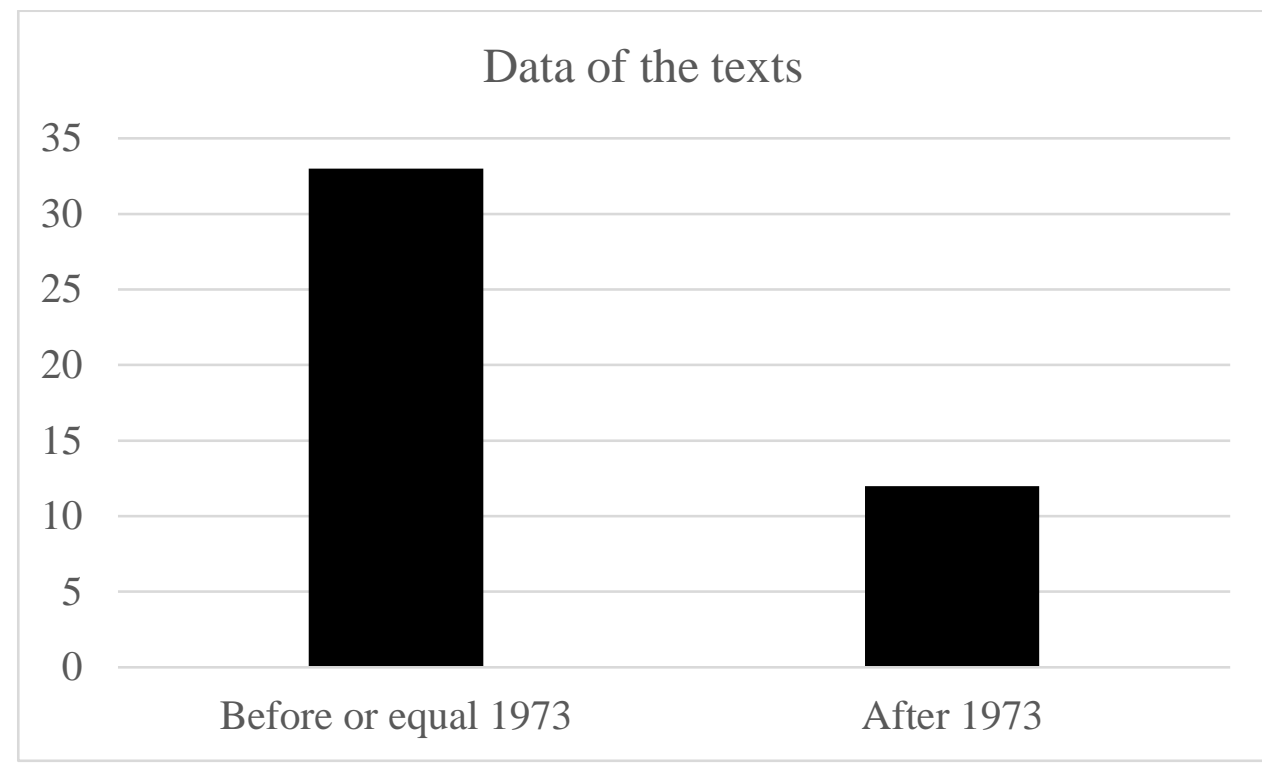

Source: Authors (2021).

Figure 2. Number of texts of the subjects studied in this work.

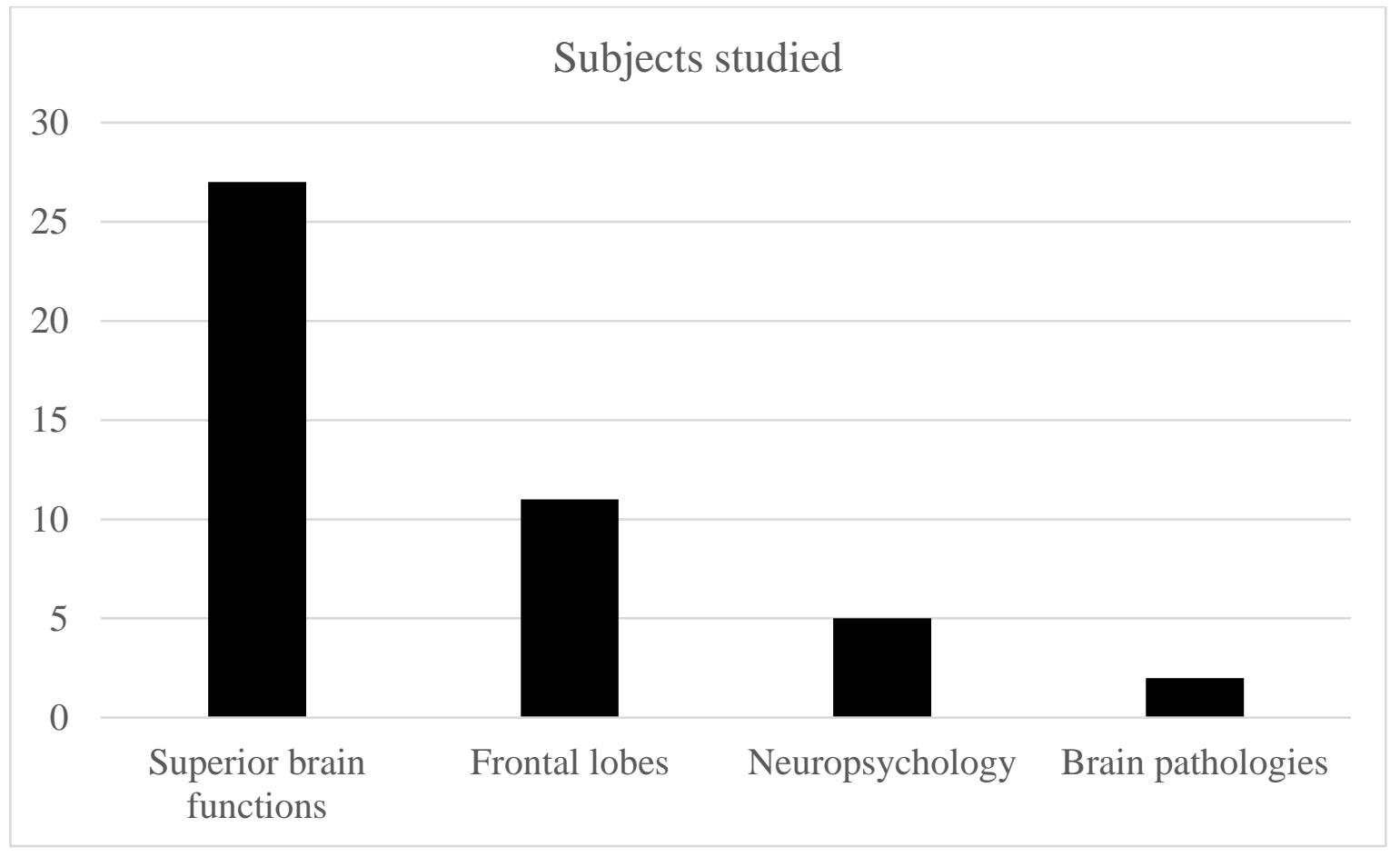

Source: Authors (2021).

\section{Discussion}

The third functional unit proposed by Luria is responsible for programming, regulating and verifying the activities associated with the regulation of the complex conscient activities. In histological terms, the third area with small and granular cells to permit reasoning, abstract activities and complex functions because the presence of the no specificity granular neurons 
permits the union of many data that are integrated by secondary areas to generate an adequate and large perception (Konorski \& Lawicka, 1964).

The frontal lobe is the main site of the third functional unit of the brain (for a simplification using the anatomical division), located anteriorly to the central gyrus, in the of Brodmann areas 9, 10 and 46 in the prefrontal lobe, and acts on the Betz cells in the precentral gyrus, the output of the brain information using the motor supplementary or premotor area, specifically the cortical part in which there are superior layers containing the pyramidal neurons that control the complex movements organized into vertical striations (Polyakov, 1965, 1966). The functional unit II is placed involving the inferior parietal, anterior occipital and superior-posterior temporal lobes in the convex aspect of the brain that is also formed by primary secondary and tertiary neuronal cortical layer. It need be cited as a base of the information sent to functional unit III.

The tertiary area formed by the granular neurons, in the second and third functionals units demonstrated different pathways in relation to information processing, i.e., in the second functional unit the information comes from the internal and/or external environment following from the primary area to the second and tertiary ones where the synthesis of the information occurs. On the other hand, the direction/way of the data from the third functional unit is the opposite, i.e., opposite because, after the synthesis of information in the tertiary areas, that generates a decision, it follows from the tertiary area to the secondary and primary motor areas (Luria, 1973) to respond the sensorial information.

The functional unit III sends and receives data from all parts of the cortex in a constant movement of information, finalizing in the precentral gyrus, which send stimulus to the muscles (McCulloch, 1943).

Around $25 \%$ of the encephalon mass is placed on the prefrontal lobe, a superstructure showing universal functions (Konorski \& Lawicka, 1964; Luria, 1973) because cellularly it is composed, as cited, of granular neurons without modal specialization. These features are specially linked to Luria's third functional unit and are associated with intentions and plans, regulation and verification of the complex behaviour in humans (Luria, Simernitskaya \& Tubylevich, 1970).

For that, a rich reciprocal connection system must be established with other cortex areas, including the pulvinar, limbic regions (Sugar et al., 1950; Pribram 1961, 1971; Pandya \& Kuypers 1969), at least to complete the final functions. Into these cited and complex functions, the cortical activation/inhibition must be modulated, therefore the reticular formation under the prefrontal lobe controls excitation, a fact demonstrated by electrophysiological data (French, Hernández-Pen \& Livingston, 1955; Pribram, 1960; Durinyan \& Rabin, 1968), under inhibition process (Konorsky et al., 1964, Brutkowsky 1964, 1966) in studies about conditioned reflexes in animals. These functions are under control of the functional unit I of the Luria.

According to Luria's group (Homskaya, 1966, 1969; Baranovskaya \& Homskaya, 1966; Artemeva \& Homskaya, 1966; Luria, 1973) the basal medial area of the prefrontal lobe exerts a strong general activation controlled by speech, showing a regulatory play in the complex intentions and plans. This region is asymmetric in both sides of the frontal lobe, exerting different functions, and its destruction does not perturb motor actions (Brutkowsky, 1964; Gross \& Weiskrantz 1964).

According to theorists of socio-cultural psychology, the high process of mental activities in humans is based on speech activities (Vygotsky 1956, 1960; Leontiev 1959) developing in accord to the society evolution. Luria state that the construction of the high human cognition is linked to the speed because the formation of ideas and abstracts schemes, in short, as the lateralization of functions, hand preferences symbology (Silva \& Guaresi, 2021). In this sense, electrical expectancy waves after a stimulus start on the frontal lobe and spread through all the cortices, increasing and diminishing according to the materialization of the expectation (Walter, 1966), plus the intellectual activities also evoke prefrontal lobe activation (Livanov, Gavrilova \& Aslano, 1964) as associating the Broca with Wernicke areas as the main via of integration of information, i.e., the using the longitudinal fascicle that integrate the speech areas. Thus, this seems to be an important aspect for specialists thinking in the purpose of using speech analysis in clinical work as base to analysis the human cognition and to use as aspect to patient treatment. For instance, positive verbal reinforcement for change some behavior (indeed, it must be development in other work). 
The functions of the frontal lobe in general and the prefrontal lobule specifically, cited above, were demonstrated in animal experiments in which the frontal lobe was removed (Pavlov, 1949a, 1949b; Konorski \& Lawicka, 1964) generating a deep behavioural modification, such as loss of objective, response to all irrelevant stimulus, therefore the animal loses the capacity to keep plans and goals (Anokhin, 1949), to accomplish complex behaviour and internal programmes and, also, shows high disinhibitions ((Brutkowski et al., 1956; Brutkowski, 1966).

Aspects such as conditioned and circular reflexes are kept, but the present and future orientation are lost in animal lobotomized. This is another important point for clinicians, i.e., the exploration of the future perspective of patients with frontal problems, since the lobotomized animals do not correct mistakes because of the absence of the reverse influence for correction of actions (Miller, Galanter, \& Pribram, 1960; Berstein, 1966; Anokhin 1971) made effective by the prefrontal lobe. The analysis of the frontal lobe lesions related to it structures and treatment of related pathologies, however, the use the aspect of the future perspectives can be developed for treatment of depression using the speech reinforcement, citing just one example.

\section{Conclusions}

Summarizing Luria's the study of the third functional unit showed functions such as stimulus synthesis, preparation for action, to program constructions, verification of the activity's ways, generation of activation process linked to the most complex conscious actions plus a speech collaboration.

Thus, a clinical approach could be used considering aspects such as speech and analysis of activities in relation to the future perspectives to generate goals for patients, for instance to depression treatment.

From the above considerations about the vast work of Luria, it is reasonable to ask 1] whether the basis of the hodiern neuropsychology maintains the identical analysis of the structural and physiological interpretation of the cerebral functions; therefore studies associating Luria's discoveries with modern ones could be undertaken; 2] whether the concepts of the third functional unit could indicate a clinical approach using speech and the promotion of goals for the patient; 3] texts on neurology and psychiatry and identical areas could add neuropsychology and functional data for students which would foment an important area to research.

\section{Acknowledgments}

The authors are grateful for the helpful comments made by the anonymous reviewers who improved the presentation and scientific quality of this article.

\section{References}

Anokhin, P. K. (1949). Problems of Higher Nervous Activity. Moscow: Publishing House of the USSR Academy of Medical Sciences.

Anokhin, P. K. (1972). Fundamental Problems in the General Theory of Functional Systems. Publishing House of the USSR Academy of Medical Sciences.

Artemieva, E. Y., \& Homskaya, E. D. (1966). Changes in asymmetry of the slow waves in various functional states under normal conditions and in lesions of the frontal lobes. In The Frontal Lobes and Regulation of Psychological Processes (pp. 53-70). Academic Press.

Aversi-Ferreira, T. A., Araújo, M. F. P. D., Lopes, D. B., \& Nishijo, H. (2010). History, citoarchitecture and neurophysiology of human and non human primates' parietal lobe: A review. Dementia \& neuropsychologia, 4(3), 173-180.

Aversi-Ferreira, T. A., Tamaishi-Watanabe, B. H., Magri, M. P. D. F., \& Aversi-Ferreira, R. A. (2019). Neuropsychology of the temporal lobe: Luria's and contemporary conceptions. Dementia \& neuropsychologia, 13(3), 251-258.

Baranovskaya, O. P., \& Homskaya, E. D. (1973). Changes in the electroencephalogram frequency spectrum during the presentation of neutral and meaningful stimuli to patients with lesions of the frontal lobes. In Psychophysiology of the frontal lobes (pp. 71-88). Cambridge: Academic Press.

Barbosa, S. M. C. ., Silva, H. E. da ., Silva, E. N. da ., \& Lima, L. O. F. (2021). Subjective relationships mediating the teaching constitution process in non school environment . Research, Society and Development, 10(4), e47710413898. https://doi.org/10.33448/rsd-v10i4.13898 
Bernstein, N. A. (1966). Outlines of the Physiology of Movements and the Physiology of Activity. Meditzina Publ.

Brutkowski, S. (1966). Functional peculiarities of the silent zones of the frontal lobes in animals. In The Frontal Lobes and Regulation of Psychological Processes. (pp.109-115). Academic Press.

Brutkowski, S. (1964). Prefrontal cortex and drive inhibition. In The frontal granular cortex and behavior (pp. 242-270). McGraw-Hill.

Brutkowski, S., Konorski, J., Lawicka, W., Stepien, I., \& Stepien, L. (1956). The effect of the removal of frontal poles of the cerebral cortex on motor conditioned reflexes. Acta Biol. Exp., 17:167-188.

Caixeta, M. et al., (2015a). Vygotsky: Psiquiatria/Psicologia do desenvolvimento. Sparta.

Caixeta, M. et al., (2015b). Psiquiatria e psicologia do desenvolvimento. Sparta.

Durinyan, R. A. \& Rabin, A. G. (1968). Cortical Regulation of Activity of the Subcortical Formations of the Brain. Tbilisi.

French, J. D., Hernández-Pen, R., \& Livingston, R. B. (1955). Projections from cortex to cephalic brain stem (reticular formation) in monkey. Journal of Neurophysiology, 18(1), 74-95.

Gross, C. G., \& Weiskrantz, L. (1964). Some changes in behavior produced by lateral frontal lesions in the macaque. In The frontal granular cortex and behavior, (pp. 74-101). New York: McGraw-Hill.

Homskaya, E. D. (1966). Vegetative components of orienting reflex to indifferent and significant stimuli in patients with lesions of the frontal lobes. In Frontal Lobes and Regulation of Psychological Processes. (pp. 190-253). Academic Press.

Konorski, J., \& Lawicka, W. (1964). Analysis of errors by prefrontal animals on the delayed-response test. In The frontal granular cortex and behavior (pp. 271294). McGraw-Hill.

Leontiev, A. N. (1959). Problems of mental development. Izdatelstvo

Livanov, M. N., Gavrilova, N. A., \& Aslanov, A. S. (1964). Intercorrelations between different cortical regions of human brain during mental activity. Neuropsychologia, 2(4), 281-289.

Luria, A. R. (1966). Higher Cortical Functions in Man. Basic Books.

Luria, A. R., Simernitskaya, E. G., \& Tubylevich, B. (1970). The structure of psychological processes in relation to cerebral organization. Neuropsychologia, 8(1), 13-19.

Luria, A. R. (1971). Memory disturbances in local brain lesions. Neuropsychologia, 9(4), 367-375

Luria, A. R. (1973a). The working brain: An introduction to neuropsychology. Basic books.

Luria, A. R. (1973b). The neuropsychology of memory. VH Winston \& Sons.

Luria, A.R. (1979). The making of mind. Harvard University Press.

Luria, A. R. (1987a). The Mind of a Mnemonist: A Little Book about a Vast Memory. Harvard University Press.

Luria, A. R. (1987b). The Man with a Shattered World: The History of a Brain Wound. Harvard University Press.

Luria, A. R., \& Rapoport, M. Y. (1962) Regional symptoms of disturbance of the higher cortical function in intracerebral tumours of the left temporal lobe. Vopr Neirokhir.; 4(1): 37-41.

Miller, G. A., Galanter, E., \& Pribram, K. H. (1960). Plans and the organization of behavior. Holt, Rinehart and Winston.

McCulloch, W. S. (1943). Interareal interaction of the cerebral cortex. In The precentral motor cortex. Chicago: Illinois Med, Dent Monographs.

Pandya, D. N., \& Kuypers, H. G. (1969). Cortico-cortical connections in the rhesus monkey. Brain research, 13(1), 13-36.

Pavlov, I. P. (1949a). Complete Collected Works, vois. 1-6. Izvestiia Akademii Nauk SSSR.

Pavlov, I. P. (1949b). Pavlov 's Wednesday Clinics, vols. 1-3. Izvestiia Akademii Nauk SSSR.

Polyakov, G. I. (1965). Principles of the Neuronal Organization of the Brain. Moscow University Press.

Polyakov, G. I. (1966). Structural organization of the frontal cortex in relation to its functional role. In Frontal Lobes and Regulation of Psychological Processes. (pp. 38-60). Cambridge: Academic Press.

Pribram, K. H. (1960). A review of theory in physiological psychology. Annual review of psychology, 11(1), 1-40.

Pribram, K. H. (1961). A further experimental analysis of the behavioral deficit that follows injury to the primate frontal cortex. Experimental neurology, 3(5), 432-466.

Pribram, K. H. (1971). Languages of the brain: Experimental paradoxes and principles in neuropsychology. 
Research, Society and Development, v. 10, n. 7, e48210716760, 2021

(CC BY 4.0) | ISSN 2525-3409 | DOI: http://dx.doi.org/10.33448/rsd-v10i7.16760

Silva, L. P. da ., \& Guaresi, R. (2021). The (dis) symmetrization in initial literacy and its possible association with linguistic and cognitive variables . Research, Society and Development, 10(4), e26310412792. https://doi.org/10.33448/rsd-v10i4.12792

Sugar, O., Petr, R., Amador, L. V., \& Griponissiotis, B. (1950). Cortico-cortical connections of the cortex buried in the intraparietal and principal sulci of the monkey (Macaca mulatta). Journal of Neuropathology \& Experimental Neurology, 9(4), 430-437.

Vygotsky, L. S. (1960). Development of higher psychological function. APN RSFSR.

Vygotsky, L. S. (1956). Selected psychological studies. Izd. APN RSFSR.

Vygotsky, L. S. (2004). Teoria e método em psicologia. Martins Fontes.

Walter, W. G. (1966). Role of the human frontal lobes in the regulation of activity. In The Frontal Lobes and Regulation of Psychological Processes. (pp. 109122). Academic Press. 